\title{
Drought monitoring of forest vegetation using MODIS-based normalized difference drought index in Hungary
}

\author{
András GULÁCSI ${ }^{1}$ and Ferenc KOVÁCS ${ }^{1}$
}

\begin{abstract}
In this paper, several spectral indices based on spectral reflectance data from the Terra satellite's Moderate Resolution Imaging Spectro-radiometer (MODIS) sensor were evaluated in terms of their practical applicability for quantifying drought intensity and its geographical effects to support the drought monitoring applications. A total number of 358 MODIS 8-day composite images for the period between 2000 and 2014 were acquired and processed for the analysis; the frequency of drought phenomenon was increased during this time period. Vegetation indices, water indices, and combinations of both, which were called drought indices, were used. To validate the results, regression analyses were performed and Pearson's $r$ values were calculated. The Pálfai Drought Index $(P A I)$ and the average annual yields of different crops were used as reference data. The Normalized Difference Vegetation Index (NDVI), the Difference Vegetation Index $(D V I)$, the Normalized Difference Water Index (NDWI), the Difference Water Index (DWI), the Difference Drought Index (DDI), and the Normalized Difference Drought Index (NDDI) were found to be significant in quantifying drought intensity. Anomalies relative to the average of the period between 2000 and 2014 were calculated and standardized using the standard deviation, enabling the identification of above-average, drought-stricken areas. The results of this study can be used to create a cost-effective, near real-time and currently missing national drought monitoring system with high temporal resolution to detect regional climate changes, and to assess forest damage probability through changes in the chlorophyll and water content of forest vegetation.
\end{abstract}

Keywords: drought, monitoring, spectral index, MODIS, NDDI, PAI.

\section{Introduction}

Hungary is frequently impacted by droughts that severely affect agricultural production and cause substantial economic damage (145 million USD annually). Therefore, it is essential to investigate the possibility of artificial groundwater recharge, as well as water retention behind river dams, in order to moderate the decline of available water resources needed for irrigation in the region. Moreover, the possible effects of climate change must also be accounted for in order to implement an effective spatial planning for national climate adaptation. According to the guidelines of the International Commission on Irrigation and Drainage (ICID, 2016), when precipitation cannot satisfy water needs because there is a large deficit compared to normal or expected precipitation that extends over a long time period, then there is a drought.

Meteorological droughts are characterized by substantially reduced rainfall compared to the multi-year average, coupled with air temperatures exceeding the average and low relative humidity. The percentage of blockingrelated warm temperature extremes exceeds 80 per cent in large continental regions north of $45^{\circ} \mathrm{N}$ (SHaw, A.T. et al. 2016). Most of the large drought events are caused by blocking anticyclones. The term "agricultural drought" refers to a shortage of water in the root zone of crops, such that the yield of plants is reduced considerably. Agricultural droughts can be observed and monitored effectively using satellite imagery and field measurements.

\footnotetext{
${ }^{1}$ Department of Physical Geography and Geoinformatics, University of Szeged, PO Box 653, H-6701 Szeged, Hungary. E-mails: guland@protonmail.com, kovacsf@geo.u-szeged.hu
} 
The aims of this study were to monitor the effects of droughts through biophysical changes on forest vegetation, determine the practical applicability of spectral indices calculated from MODIS sensor data collected by NASA's Terra satellite, and calculate the trend in drought intensity. The results can be used to create a near real-time drought monitoring system to assess agricultural and forest drought damage.

This study is a culmination of our earlier methodological developments in drought assessment through changes in vegetation canopies and biomass (KovÁcs, F. 2007; GulÁCsI, A. and Kovács, F. 2015).

\section{Review of applied spectral indices}

Multispectral vegetation indices - thanks for the AVHRR sensor - have been in use for decades in real-time monitoring of drought (Kogan, F.N. 1995). In general, greennessrelated vegetation indices such as the Normalized Difference Vegetation Index (NDVI) and the Enhanced Vegetation Index (EVI) are used (Rouse, J.W. et al. 1973; Solano, R. et al. 2010). U.S. Drought Monitor (DM) uses the Vegetation Health Index (VHI) which is calculated using linearly-scaled NDVI and brightness temperature data from AVHRR.

However, there is a need to evaluate the sensitivity of water-related vegetation indices that use the short-wave infrared (SWIR) bands to assess the shortage of water and associated impacts (BAJGAIN, R. et al. 2015). Absorption by the chloroplasts of healthy vegetation is high in the visible wavelength range because of intensive photosynthesis. If the chlorophyll content decreases, the absorption will also decrease. In contrast, dry and unhealthy vegetation canopies with lower chlorophyll contents have lower NDVI values, because the reflectance in the visible red channel is increased at the same time that the reflectance in the NIR channel, which is located at the high reflectance plateau, decreases. EVI is an NDVI variant that includes correction factors for minimizing atmospheric ef- fects and removing soil-brightness induced variations. Generally, EVI is more exact than NDVI, but surfaces covered with quasi-natural vegetation in regional scale can be evaluated better with NDVI (LI, Z. et al. 2010).

NDVI provides information on vegetation greenness or chlorophyll content, which are not directly related to vegetation water content (VWC) because, as summarized by Ceccato, P. et al. (2002), each species has its own characteristics in terms of chlorophyll content and water content. Thus, a decrease in chlorophyll content does not imply a decrease in water content, and a decrease in water content does not imply a decrease in chlorophyll content. However, numerous water indices have been developed that are suitable for quantifying VWC. Absorption by vegetation liquid water in the NIR channel is negligible, while in the SWIR channel it is very high. If VWC decreases, then reflectance in the SWIR channel increases significantly. Thus, the Normalized Difference Water Index (NDWI) value - that combines information from the NIR and the SWIR bands - decreases, reflecting dry vegetation that is experiencing drought stress (GAO, B-C. 1996). NDWI is one of the indicators implemented within the European Drought Observatory (EDO).

Ceccato, P. et al. (2001) demonstrated that remote sensing using the SWIR wavelength range is critical, but not sufficient, for retrieving VWC because two other leaf parameters (internal structure and dry matter) are also responsible for leaf reflectance variations in the SWIR channel. The NIR channel is needed to account for variations in leaf internal structure and dry matter. Thus, a combination of the SWIR and NIR channels is required to retrieve VWC. Сессато, P. et al. (2002) developed and tested a NIR-SWIR-based index called Global Vegetation Moisture Index (GVMI). It was sensitive to the mass or volume of water, rather than to the fractional percentage of water in vegetation canopies.

JACKsON, T.J. et al. (2004) used Landsat data-derived NDVI and NDWI values to map VWC in corn and soybean fields. Compared to NDVI, NDWI was found to be superior, 
based upon a quantitative analysis of the bias and standard error. CHEN, D. et al. (2005) found that both $N D W I_{1640}$, which uses the SWIR band centred at 1,640 nm, and $N D W I_{2130}$, which uses the SWIR band centred at 2,130 $\mathrm{nm}$, derived from MODIS data covering corn and soybean fields had potential for VWC estimation.

Gu, Y. et al. $(2007,2008)$ concluded that NDWI reacts more sensitively to drought conditions than NDVI. Gu, Y. et al. (2007) used MODIS surface reflectance data and introduced the Normalized Difference Drought Index (NDDI) by combining NDVI with NDWI.

ZHANG, N. et al. (2013) proposed a MODISbased visible and shortwave infrared drought index (VSDI) for monitoring both soil and vegetation moisture using the NIR channel, the visible blue channel, and the SWIR channel (centred at 2,130 nm), and proved the applicability of VSDI as a drought indicator.

The Normalized Multi-Band Drought Index (NMDI) combines the NIR and the SWIR channels centred at 1,640 $\mathrm{nm}$ and 2,130 nm from MODIS data (WANG, L. and QU, J.J. 2007). They found that NMDI is well-suited to estimate the water content of soil and vegetation. Moreover, because it combines information from multiple NIR and SWIR channels, NMDI has an enhanced sensitivity to drought severity.

\section{Data and methods}

\section{MODIS data processing and software used}

MOD09A1 (Collection 5) 500-m resolution 8-day surface reflectance composite images (Surface Reflectance 8-Day L3 Global 500 m SIN Grid) provided the basis for this study. The MODIS data covering the $89^{\text {th }}$ through the $273^{\text {rd }}$ days of each year from 2000 to 2014 were downloaded from the Land Processes Distributed Active Archive System and accessed from the USGS Global Visualization Viewer (GLOVIS). A total number of 358 images were obtained.

The main advantage of using MODIS data is the high temporal resolution (daily images are available) and the composite image technology which enables to create an 8-day or 16-day composite from the highest quality pixels, that is, free of atmospheric effects like cloud cover and shadow. The disadvantages of MODIS are the moderate geometric resolution ( 250 or 500 meters) and the data is from 2000, so that we do not have more decades of available satellite imagery like Landsat does. For the specifications about the MODIS surface reflectance data (see Vermote, E.F. et al. 2011).

The data were processed as follows. (1) The MODIS HDF data were converted into GeoTIFF format and re-projected into WGS 84 and UTM zone $34 \mathrm{~N}$ using the nearest neighbour resampling method, in order to keep the QA bit field values unchanged. (2) Cells with inaccurate or inconsistent values, which were mainly caused by cloud cover, were masked out using the Quality Control and State Flag bands; only the best quality cells were kept. (3) A subset of the data corresponding to the study area was selected. Data were re-projected to Hungarian National Projection (EOV). Finally, (4), the spectral indices were calculated.

The following programs were used for data processing, analysis, and mapping: SAGA GIS 2.1.2, QGIS 2.8.2-Wien (with Python 2.7.5 and GDAL 1.11.2), R 3.2.1 (R Core Team, 2013), LDOPE Tools 1.7 and the MODIS Reprojection Tool 4.1 (Roy, D.P. et al. 2002), and the authors' own programs that were written in the C language using the Code: Blocks 10.05 IDE. Processing was automated using Python and command line scripts.

\section{Calculation of spectral indices}

NDVI and NDWI were calculated according to equations (1) and (2):

$$
N D V I=\frac{\rho_{\text {NIR }}-\rho_{\text {red }}}{\rho_{\text {NIR }}+\rho_{\text {red }}},
$$

and

$$
N D W I=\frac{\rho_{\text {NIR }}+\rho_{\text {SWIR }}}{\rho_{\text {NIR }}-\rho_{\text {SWIR }}},
$$


where NDVI = Normalized Difference Vegetation Index, NDWI = the Normalized Difference Water Index, $\rho_{\text {red }}=$ the visible red channel $(620-670 \mathrm{~nm}), \rho_{\text {NIR }}=$ the near infrared channel (841-876 nm), and $\rho_{\text {SWIR }}=$ one of the middle infrared channels $(2,105-2,155 \mathrm{~nm})$ measured by the MODIS sensor. Normalized Difference Drought Index (NDDI) is calculated from NDVI and NDWI according to equation (3) (GU, Y. et al. 2007):

$$
N D D I=\frac{N D V I-N D W I}{N D V I+N D W I},
$$

In spite of the quality assessment, extreme negative and positive NDDI values may result from this calculation, but it only affects a small number of cells in cases with large open water surfaces and built-up areas. These have to be removed. Gu, Y. et al. (2007) removed spike points (e.g. abnormally high values) from NDWI time series by using a quality assurance (QA) mask before calculating NDDI. On the other hand, RenzA, D. et al. (2010) rescaled NDVI and NDWI into the 8-bit interval (from 0 to 255) in order to force the NDDI values into the range of -1 and +1 . This rescaling is unnecessary step, so it was not used here. Simple difference indices were calculated as well, according to equation (4):

$$
D D I=D V I-D W I,
$$

where $D D I=$ Difference Drought Index, DVI $=$ Difference Vegetation Index (Tucker, C.J. 1980), DWI = Difference Water Index (ZHANG, D. et al. 2013). DVI $=\rho_{\text {NIR }}-\rho_{\text {red }}$ and DWI $=$ $\rho_{\text {NIR }}-\rho_{\text {SWIR }}$. These difference indices are rarely used; because they lack a normalization step, they do not compensate for different irradiational conditions (TuCKER, C.J. 1979).

To make different time periods directly comparable with each other on the same scale, standardization with the SD was applied to every cell separately. The resulting standardized spectral index is calculated according to equation (5):

$$
Z_{i j}=\frac{x_{i j}-\bar{x}_{i j}}{S D_{i j}},
$$

where $Z_{i j}=$ the standardized spectral index (Z-score value), $i$ and $j=$ the row and column number of the current cell, $x_{i j}=$ the current value of any given spectral index, $\bar{x}_{i j}=$ the average of the spectral index values for the reference period from 2000 to 2014, and $S D_{i j}$ $=$ the standard deviation of the spectral index values for the reference period.

It should be noted here that the anomalies are dependent on the time series available to calculate the mean values and the standard deviations. This period, which is currently 15 years, should be long enough to characterize the area where the index is being calculated.

\section{Reference data and statistical analysis}

The Pálfai Drought Index $(P A I)$ is commonly used in Hungary, and it is an annual index aggregated at country level. Its base value $\left(P A I_{0}\right)$ is calculated from daily temperature and precipitation time series using equation (6):

$$
P A I_{0}=\frac{T_{(A p r-A u g)}}{P_{(\text {Oct-Aug) }}} \cdot 100 \text {, }
$$

where $P A I_{0}=$ the base value of Pálfai Drought Index, the $T_{(A p r-A u g)}=$ the average temperature for the period between April and August, and $P_{\text {(Oct-Aug) }}=$ the monthly weighted sum of precipitation for the period between October and August. The units of this quantity are ${ }^{\circ} \mathrm{C} / 100$ $\mathrm{mm}$. The corrected $P A I$ value is obtained by multiplying $P A I_{0}$ with empirical correction factors, according to equation (7) (PÁLfAI, I. 1989):

$$
P A I=P A I_{0} \cdot c_{t} \cdot c_{p} \cdot c_{g w},
$$

where $c_{t}=$ the correction factor for temperature, $c_{p}=$ the correction factor for precipitation, and $c_{g w}=$ the correction factor for groundwater levels (not discussed in detail).

In addition to $P A I$, the annual average crop yields ( $\mathrm{kg} / \mathrm{ha})$ of barley, corn, and wheat were 
also used as reference data. The source of these data is the Hungarian Central Statistical Office (HCSO). The whole-country aggregated mean of spectral indices were compared to the wholecountry mean of PAI and crop yields data.

Unfortunately, the limited access to reference data confined our options in validating the results. Pearson's $r$-values were calculated and the Mann-Kendall test was used to assess the significance of the fitted trends.

\section{Delineating forest vegetation for drought monitoring}

Caution needs to be taken when using any sort of spectral indices for remote sensing of drought, because land cover changes resulting in removal of vegetation (such as the opening of surface mines, deforestation, forest fires, and harvest of arable land) may be confused with areas experiencing drought. Accurate drought monitoring can only be accomplished when we are able to accurately delineate cells with vegetation cover and exclude all the cells that are affected by land cover change. We decided to monitor drought over forest vegetation, because the chlorophyll and VWC of trees are highly sensitive to drought conditions; they are thus good indicators of drought. In addition to multi-year fluctuations, it may be possible to detect short-term effects of climate change on drought conditions via vegetation changes. However, a longer time period is needed to assert with certainty that these changes were indeed the result of alterations in climatic conditions. High-amplitude multi-year fluctuations in drought intensity can suppress the increasing trend in aridity.

Forest covered areas were delineated using the European Union's Corine Land Cover (CLC) datasets covering the years 2000, 2006, and 2012. The CLC is an inventory of land cover that includes 44 classes. It is presented as a cartographic product with a scale of 1:100,000 (EEA). Sub-setting was carried out as follows. For the period from 2000 to 2005, the CLC 2000 land cover database was used; for the period from 2006 to 2011, the CLC 2006 land cover database was used; and finally, for the period between 2012 and 2014, the CLC 2012 land cover database was used. The spatial resolution of the available satellite imagery did not allow the precise evaluation of the heterogeneous land cover characterizing the study area. To overcome this problem, only so called representative pixels were considered (Kovács, F. 2007). A pixel was representative if two third of its area was dominated by the same land cover. The class of forests was subdivided into deciduous, coniferous, and mixed forest categories.

\section{Study area}

Hungary is located in East Central Europe in the middle of the Carpathian Basin. According to the Köppen-Geiger climate classification system (PEeL, M.C. et al. 2007), the country has a humid continental climate without a dry season and with warm summers. The annual mean temperature is between $10-11{ }^{\circ} \mathrm{C}$, and the annual total precipitation is between 500-750 $\mathrm{mm}$ on average (Hungarian Meteorological Service). The study area is the DanubeTisza Interfluve landscape, which is located within the lowlands of the Great Hungarian Plain, between the Danube and Tisza rivers (Figure 1). It has elevations below $200 \mathrm{~m}$ in elevation and has a total area of $15,000 \mathrm{~km}^{2}$. It is an agricultural region with intensive forestry.

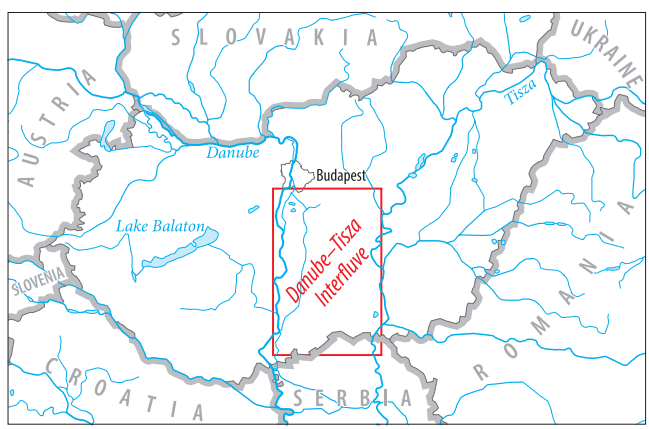

Fig. 1. The location of the study area inside Hungary 
The Danube-Tisza Interfluve has been experiencing aridification during the past several decades, which has caused a decline of 250-300 cm in groundwater levels between the base period of 1956-1960 and the mid1990s (VITUKI, 2006). The water balance of the landscape is persistently negative. It is estimated that, from the mid-1970s to 2003, there was a water deficit of $5 \mathrm{~km}^{3}$ (RAKONCZAI, J. 2011). The central parts of the Danube-Tisza Interfluve are 40-80 m above river water levels; the effect of the rivers thus is only detectable in narrow regions around the rivers. The recharge of the water supply depends only on the precipitation the region receives. Based on regional hydrological models using MODFLOW, the decline in annual precipitation is contributing 80 per cent of the groundwater decline in the area (VöLgyesI, I. 2000). Climate models project increasing drought hazard in the Carpathian Basin. More frequent and severe droughts have already caused significant agricultural yield losses in recent decades (Mezôsi, G. et al. 2016).

The suggestion that alterations in climatic conditions may also occur over shorter time intervals (Kovács, F. 2007) might have some validity here because this landscape has considerable sensitivity to climate change. It is the reason why we chose this rapidly changing landscape as our study area.

\section{Results}

\section{Monitoring drought intensity with NDDI and determining the trend in aridity}

In 2000 the areas occupied by deciduous, mixed, and coniferous forest were 42,527 ha, 45,892 ha, and 16,528 ha, respectively. In 2006 the areas of deciduous, mixed, and coniferous forest were 58,234 ha, 45,827 ha, and 15,819 ha, respectively. Finally, in 2012, the areas of deciduous, mixed, and coniferous forest were 55,808 ha, 37,241 ha, and 9,917 ha, respectively. The area of deciduous forest increased from 2000 to 2012. The area of mixed forest was practically unchanged from
2000 to 2006. It subsequently declined by 19 per cent by 2012. An astonishing 37 per cent of the area covered by coniferous forests was deforested between 2006 and 2012. The base map of MODIS cells representing deciduous, mixed, and coniferous forests on the DanubeTisza Interfluve in 2012 is shown in Figure 2.

After masking out cells with inappropriate values, the number of valid cells was reduced slightly. In addition, 16 large positive outliers (with Z-score values > 1.75) in the period between 2006 and 2011 were removed because of deforestation. In each of the five-year periods (2000-2005, 2006-2011, 2012-2014), the following numbers of cells were removed from the areas covered by each of the forest types: deciduous forests: none, 2 , and 1 ; mixed forests: 4, 5, and 6; and coniferous forests: 1,63 , and 1 , respectively (the removals had negligible effect on the results). The standardized NDDI images were reclassified as follows. Non-drought areas were indicated by Z-score values less than or equal to 0.0 , whereas drought areas were indicated by Z-score values above 0.0 .

Nonetheless, it should be noted that the drought phenomena may not have a clear-cut boundary. In addition, the low spatial resolution makes it impossible not to make abrupt boundaries. Positive deviations from the mean indicate higher likelihood of drought; negative deviations mean the opposite.

Based on NDDI, in the period between 2000 and 2005, 85.4 per cent of the cells (38,894 ha) exceeded the average of the reference period. This quantity was 20.3 per cent $(11,827 \mathrm{ha})$ in the period between 2006 and 2011, and it was 17.2 per cent $(9,573 \mathrm{ha})$ in the period between 2012 and 2014 for deciduous forests. In the case of mixed forests, 72.0 per cent (32,970 ha), 17.2 per cent (7,856 ha) and 22.0 per cent $(8,178 \mathrm{ha})$ were above average, respectively. Finally, in the case of coniferous forests, 36.3 per cent $(5,989$ ha), 26.9 per cent ( $3,885 \mathrm{ha})$, and 18.7 per cent $(1,846 \mathrm{ha})$ were above average, respectively. The areal coverage of drought is higher in deciduous forests than in coniferous forests. However, in the period between 2012 and 2014 the percentage of drought-stricken area is a little bit higher 


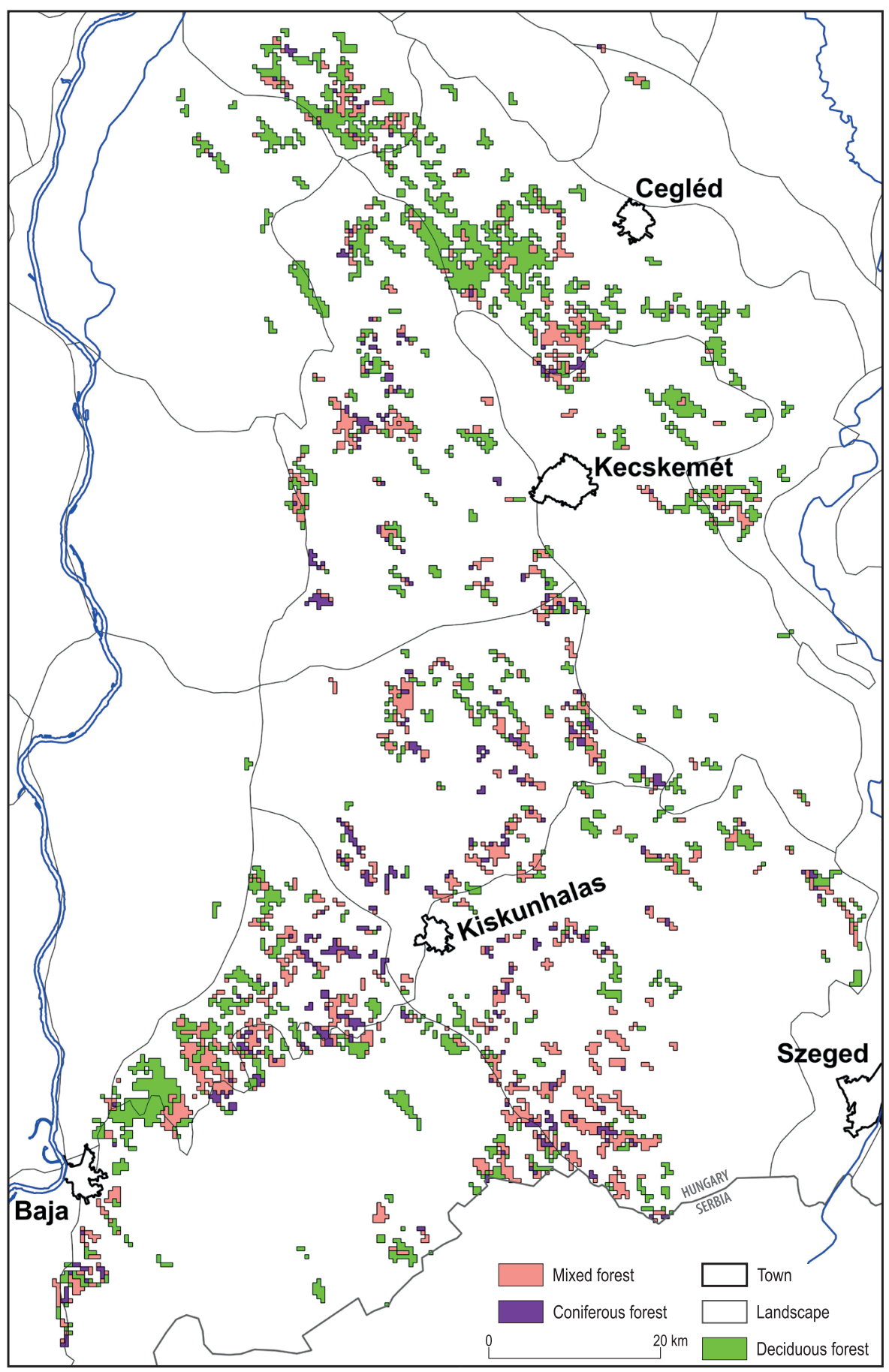

Fig. 2. Representative cells containing deciduous, mixed, and coniferous forests in the study area in 2012. Red lines indicate geographic landscape boundaries. 
in coniferous forests than in deciduous forests. Drought-stricken areas of mixed forests slightly increased in the last period. These differences are not significant, and do not change the fact that coniferous forests (made up of Pinus) appear to be more drought-tolerant compared to deciduous forests (made up of Robinia, Populus) planted on the landscape.

The drought intensity was higher during the period between 2000 and 2005, since there were intense drought years (2000, 2001, 2002, and 2003). In particular, 2003 was one of the most severe droughts on record, based on the spectral indices and PAI. Since then, a decrease in drought intensity has been observed. In the box plot (Figure 3), the period between 2000 and 2005 stands out, and the following periods of 2006-2011 and 20122014 reflects less intensive drought conditions. There were drought years $(2007,2009$ and 2012) during these periods as well, but they were surpassed by the large droughts of the early 2000s in terms of their intensity.

Because of the lack of annual land cover assessment, changes in forest cover may not be fully accounted for by the Corine land cover assessments, which are made every 5 or 6 years. Therefore, even though outliers were removed, the median was used, since the arithmetic mean is sensitive to extreme values. It has been found that coniferous forests have larger mean NDDI values compared to the other forest types. Additionally, 2009 stands out as having the second highest median after 2003. Deciduous forests have the smallest medians; the second largest drought was in 2000. In the case of all three time series, the same drought pattern is observable but with a different ranking of drought years; however, 2003 has the largest median in every series. The drought years were 2000, 2001, 2002, 2003, 2007, 2009, 2011 and 2012. Interestingly, the coniferous forests reflect drought in 2011, rather than in 2012. Subsequent drought- and non-drought years (2003-2004, 2006-2007) have marked differences (22-30\%) in median values (Figure 4).

The significance of the fitted linear trends was evaluated by the Mann-Kendall test with no correction for autocorrelation, since the time

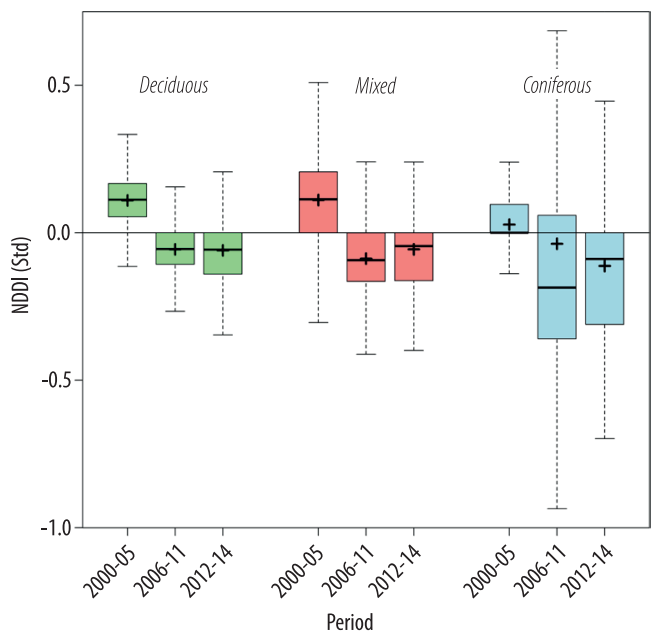

Fig. 3. Boxplot of standardized NDDI values for deciduous, mixed, and coniferous forests. Outliers were omitted from the graph. Crosses indicate the arithmetic mean values. Note the wide range of the whiskers in case of coniferous forests in 2006-2011. There are also substantial gaps between the arithmetic mean and median values. These gaps are caused by positive outliers, which were removed afterwards.

series are not auto-correlated. It was concluded that, in the case of deciduous and mixed forests, NDDI does not show any significant monotonic decreasing trend $(p=0.14, p=0.06$, respectively) during the examined period. On the other hand, for coniferous forests, a decreasing trend was found to be significant at the $p<0.05$ level. However, it was not accepted either, because the decreasing trend is likely an artefact of the large droughts of the early 2000s. Drought maps were also created for every year during the examined period (Figure 5).

\section{Validation of results}

Linear regressions were applied to characterize the statistical connection between the annual average of spectral indices and the Pálfai Drought Index (PAI). In addition to Pearson's r values, the statistical significance levels were given as well. The normalized versions (NDVI and NDWI) performed better 


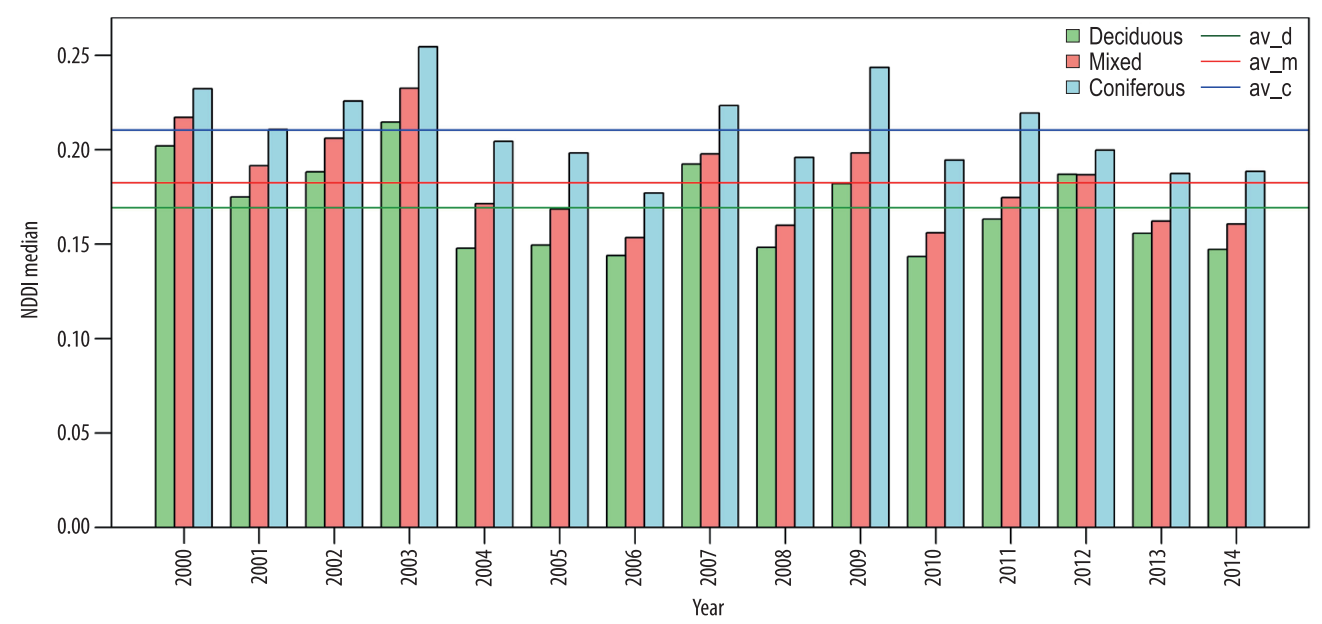

Fig. 4. Barplot showing the median of NDDI in the examined years for deciduous, mixed, and coniferous forests. Coloured lines indicate the average of the medians as the drought threshold limit ( $a v_{-} d$ is the average for deciduous forests, $a v_{-} m$ is the average for mixed forests, and $a v_{-} c$ is the average for coniferous forests).

( $r$ is -0.90 and -0.92 with $P A I$, respectively). On the other hand, the drought indices performed worse. DDI shows a moderate correlation with PAI. However, NDDI showed the weakest correlation based on linear regression, although it incorporates information on the chlorophyll and VWC of the vegetation.

$P A I$ is an indicator of meteorological drought. On the other hand, spectral indices represent agricultural drought. Therefore, they do not necessarily match every year. Lag effects must also be taken into consideration. For example, one year's recharge of groundwater and soil moisture can moderate agricultural drought in the following year, so that crops have sufficient water reserves. Under such circumstances, the groundwater level is elevated, enabling plants to utilize it. Thus, plants can grow normally, even if there is an ongoing meteorological drought (Table 1).

Connections with crop yield data obtained from $\mathrm{HCSO}$ were evaluated as well. A regression was performed for the 'Non-irrigated arable land' class (code 212) of the Corine Land Cover Database 2012 because, unfortunately, no data on the production area of different crops are available. The results of this analysis are shown in Table 2.
Table 1. Correlation matrix between the spectral indices ${ }^{b}$ and PAI for the period between 2000 and 2014.

\begin{tabular}{l|c}
\hline Spectral index & Correlation with PAI \\
\hline NDDI & $0.64^{*}$ \\
DDI & $0.80^{* * *}$ \\
NDVI & $-0.90^{* * *}$ \\
DVI & $-0.81^{* * *}$ \\
NDWI & $-0.91^{* * *}$ \\
DWI & $-0.87^{* * *}$ \\
\hline
\end{tabular}

aPearson's $r$; ${ }^{\text {a }}$ April-August average, including the $89^{\text {th }}$ through the $273^{\text {rd }}$ days of each year. Significance levels: ${ }^{*} \mathrm{P} \leq 0.05,{ }^{* * *} \mathrm{P} \leq 0.001$, according to a two-tailed t-test.

For the period between 18 and 25 of June, $N D D I$ and DDI have the highest correlations with barley, corn, and wheat yields. The vegetation and water indices have lower correlations with barley, corn, and wheat yields. For example, the vegetation indices have no significant connections with corn yields. NDWI displays a weak correlation with corn yields, but shows higher correlations with those of barley and wheat. On the other hand, for the period between 12 and 9 of July, NDDI and $D D I$ have slightly lower correlations with crop yields compared to the vegetation and water indices. In the case of corn, the vegetation and water indices performed best. In 


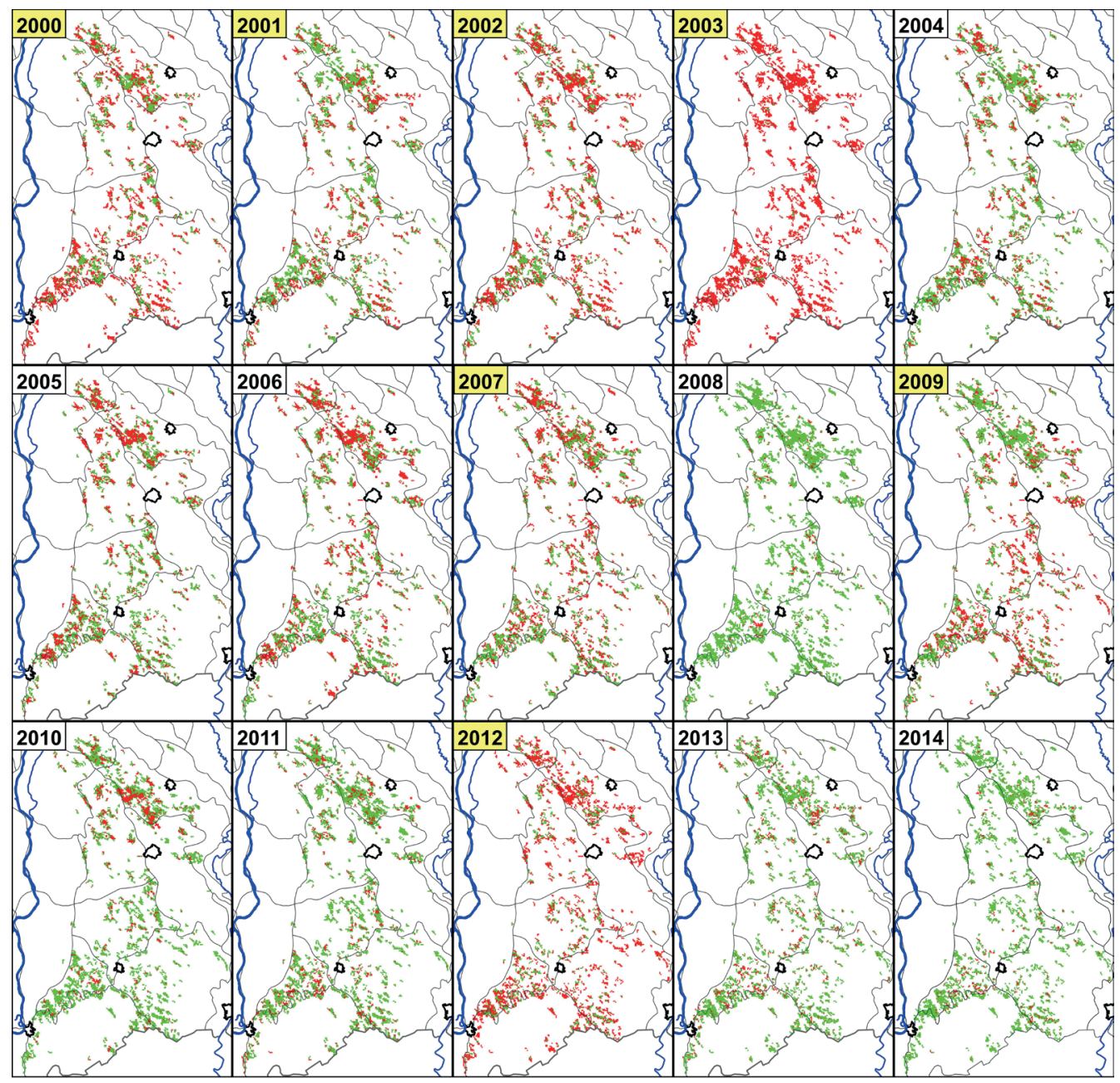

Fig. 5. Growing season NDDI averages, standardized and reclassified into drought and non-drought categories. Outliers have been removed. Drought years were highlighted with yellow background. Although large areas were drier than average in 2005 and in 2006, especially the northern parts of the study area had slightly positive anomalies, but overall, not as high as in 2007 which considered to be a drought year

contrast, in June, their performance was the weakest.

The NDDI was selected as the most appropriate method for agricultural drought monitoring. As an alternative, NDVI and NDWI can be used separately for the same task.

All spectral indices were found to be significant in quantifying drought intensity based on PAI, but normalized indices are preferred over difference indices. Further validation with ground truth data is needed to fully assess the performance of NDDI. These preliminary findings appear to be promising, however, the sample size is small, and only national averages were compared to each other. There is a pressing need to obtain more reference data to enable an extended calibration and validation process. 
Table 2. Correlation coefficients ${ }^{a}$ between the spectral indices and crop yields, and between PAI and crop yields, for the examined period ${ }^{b}$

\begin{tabular}{c|l|c|c|c}
\hline \multirow{2}{*}{ Period } & \multirow{2}{*}{ Index } & \multicolumn{3}{|c}{ Yields } \\
\cline { 3 - 5 } & & barley & corn & wheat \\
\hline \multirow{5}{*}{$18-25$ June } & NDDI & $-0.91^{* * *}$ & $-0.69^{* *}$ & $-0.79^{* * *}$ \\
& DDI & $-0.90^{* * *}$ & $-0.69^{* *}$ & $-0.77^{* *}$ \\
& NDVI & $0.57^{*}$ & 0.34 & $0.54^{*}$ \\
& DVI & $0.66^{* *}$ & 0.51 & $0.63^{*}$ \\
& NDWI & $0.83^{* * *}$ & $0.60^{*}$ & $0.75^{* *}$ \\
& DWI & $0.81^{* * *}$ & $0.63^{*}$ & $0.74^{* *}$ \\
\hline \multirow{5}{*}{$12-19$ July } & NDDI & $-0.60^{*}$ & $-0.63^{*}$ & $-0.63^{*}$ \\
& DDI & $-0.68^{* *}$ & $-0.68^{* *}$ & $-0.71^{* *}$ \\
& NDVI & $0.63^{*}$ & $0.83^{* * *}$ & $0.66^{* *}$ \\
& DVI & $0.67^{* *}$ & $0.73^{* *}$ & $0.67^{* *}$ \\
& NDWI & $0.71^{* *}$ & $0.80^{* * *}$ & $0.73^{* *}$ \\
& DWI & $0.73^{* *}$ & $0.76^{* *}$ & $0.73^{* *}$ \\
\hline Whole year & PAI & $-0.61^{*}$ & $-0.93^{* * *}$ & $-0.66^{* *}$ \\
\hline
\end{tabular}

aPearson's r; 'Spectral index averages for the 8-day periods between 18 and 25 of June and between 12 and 19 of July were used. Significance levels: ${ }^{*} \mathrm{P} \leq 0.05,{ }^{* *} \mathrm{P} \leq 0.01$ and ${ }^{* * *} \mathrm{P} \leq 0.001$, according to a two-tailed t-test. Notes: In the case of the 8-day period in June, there was one missing data point in 2001. Because of high cloud cover, it could not be replaced by the previous or the following 8-day period. In 2010, the average of the previous 8-day period between 10 and 17 of June was used instead, due to high cloud cover. In the case of the 8-day period in July in 2000, 2002, 2004, and 2012, the mean values of the spectral indexes for the 8-day period between 4 and 11 of July were used, due to high cloud cover. The harvest period starts at the end of June.

\section{Discussion and conclusions}

No indicator can fully capture the multiscale, multi-impact nature of drought, so the combination of many different parameters, indicators or indices (remote sensing data included) in a single drought classification product is required (HAYEs, M.J. et al. 2012). To look at the international level, the composite indicator approach is used by the USDM (U.S. Drought Monitor), which was initiated in 1999 and is globally considered the state-of-the-art drought monitoring tool. It produces weekly maps (SvoвоDA, M. et al. 2002). The European Drought Observatory (EDO) also created a composite called Combined Drought Indicator which is composed from Standard Precipitation Index (SPI), soil moisture and fraction of absorbed photosynthetically active radiation data (EDO 2013).

Our index product (NDDI) and cannot alone serve a basis of a national drought monitoring system, since additional in situ measurements depicting the major components of the hydrologic cycle (like tempera- ture, precipitation, soil moisture, streamflow, snow water equivalent) are also needed to fully capture the nature of drought in its complexity. Nonetheless, NDDI can be particularly useful for vegetation monitoring, since vegetation stress is may be the most detrimental consequence of drought.

The standardized NDDI was proven to be sensitive to land cover changes (afforestation or deforestation). As a result of this, a false drought signal is observed. Our results indicate that this false signal is small and only affects a few cells that can be excluded from the analysis based on standard deviation values. Therefore, it has a marginal effect on the results, but it must not be ignored. Moreover, with the use of an improved land cover assessment, the false drought signal can be minimized even more.

Interestingly, it has been found that lower positive standardized NDDI values most likely represent drought, or at least a change in drought intensity, from the chosen reference period. On the other hand, large positive deviations (even 10+ Z-scores) are 
artefacts of deforestation in the examined periods, especially in the case of coniferous forest during the period between 2006 and 2011. Moreover, afforestation or reforestation can also cause large negative deviations from the mean. This is the result of our limited capability to delineate areas with forest cover. A clear, unbiased climatic signal can only be obtained and used for detecting regional climatic trends through changes in forest vegetation canopy when we are able to minimize the effect of land cover changes.

It was concluded based on our validation process that all the spectral indices calculated from the MODIS spectral reflectance data collected by the Terra satellite in this paper were proven to be applicable for the remote sensing of drought, confirming our previous results (Gulácsi, A. and Kovács, F. 2015). The normalized difference indices (NDDI, NDWI, and NDVI) are preferred over the simple difference indices (DDI, DWI, and DVI). Basically, all of the spectral indices are only different versions of the same index or a combination of them. Chlorophyll and VWC information can be fused into one single index, the NDDI. Because of this, the use of NDDI is preferred by the authors. Using NDVI and NDWI separately is also a viable option.

These satellite indices can be computed on a real-near-time basis which largely contributes to regional drought monitoring and makes decadal-scale time series analysis possible to assess changes in drought severity.

Further research is needed to carry out an extended validation of the spectral indices using other ground truth data, such as the SPI (McKeE, T.B. et al. 1993), which is calculated from precipitation data collected at measuring stations.

Successful drought monitoring of vegetation can only be achieved when we are able to accurately delineate vegetation cover. Because we use the Corine Land Cover database and remove outliers, land cover change has only a minor effect on the results. Drought intensity shows a slight downward trend during the examined period, as the result of the large droughts that occurred in the early 2000s.
In the study, the basis of a cost-effective, near-real-time, MODIS-based drought monitoring system of vegetation was laid down. NDDI can be used as a sensitive drought assessment tool for water management, agriculture, and conservation of natural areas.

Acknowledgement: This paper was supported by the János Bolyai Research Scholarship of the Hungarian Academy of Sciences. The research was supported by the Interreg-IPA Cross-border Cooperation Programme Hungary-Serbia and cofinanced by the European Union (IPA) under the project HUSRB/1602/11/0057 entitled WATERatRISK (Improvement of drought and excess water monitoring for supporting water management and mitigation of risks related to extreme weather conditions)

\section{REFERENCES}

Bajgain, R., XIAO, X., Wagle, P., Basara, J.B. and ZHou, Y. 2015. Sensitivity analysis of vegetation indices to drought over two tallgrass prairie sites. ISPRS Journal of Photogrammetry and Remote Sensing 108. 151-160. Doi:10.1016/j.isprsjprs.2015.07.004

Ceccato, P., Flasse, S. and Gregoire, J. 2002. Designing a spectral index to estimate vegetation water content from remote sensing data: Part 2. Validation and applications. Remote Sensing of Environment 82. 198-207.

Ceccato, P., Flasse, S., Tarantola, S., Jacquemoud, S. and Grégoire, J-M. 2001. Detecting vegetation leaf water content using reflectance in the optical domain. Remote Sensing of Environment 77. 22-33.

Chen, D., HuAng, J. and JACKson, T.J. 2005. Vegetation water content estimation for corn and soybeans using spectral indices derived from MODIS near- and short-wave infrared bands. Remote Sensing of Environment 98. 225-236. Doi:10.1016/j. rse.2003.10.021

GAO, B-C. 1996. NDWI - A Normalized Difference Water Index for Remote Sensing of Vegetation Liquid Water From Space. Remote Sensing of Environment 58. 257-266.

Gu, Y., Brown, J.F., Verdin, J.P. and Wardlow, B. 2007. A five-year analysis of MODIS NDVI and NDWI for grassland drought assessment over the central Great Plains of the United States. Geophysical Research Letters 34. Doi:10.1029/2006GL0291

Gu, Y., Hunt, E., Wardlow, B., Basara, J.B., Brown, J.F. and VERDIN, J.P. 2008. Evaluation of MODIS NDVI and NDWI for vegetation drought monitoring using Oklahoma Mesonet soil moisture 
data, Geophysical Research Letters 35 (L22401). Doi:10.1029/2008GL035772

Gulácsi, A. and Kovács, F. 2015. Drought monitoring with spectral indices calculated from MODIS satellite images in Hungary. Journal of Environmental Geography 8. (3-4): 11-20. Doi:10.1515/ jengeo-2015-0008

Hayes, M.J., Svoboda, M.D., Wardlow, B.D., Anderson, M.C. and Kogan, F. 2012. Drought Monitoring. In Remote Sensing of Drought. Innovative Monitoring Approaches. Eds.: Wardlow, B.D., Anderson, M.C. and Verdin, J.P., Boca Raton, CRC Press, 1-19.

Jackson, T.J., Chen, D., Cosh, M., Li, F., Anderson, M., Walthall, C., Doriaswamy, P. and Hunt, E.R. 2004. Vegetation water content mapping using Landsat data derived normalized difference water index for corn and soybeans. Remote Sensing of Environment 92. 475-482.

Kogan, F.N. 1995. Droughts of the late 1980s in the United States as derived from NOAA polar-orbiting satellite data. Bulletin of the American Meteorological Society 76. (5): 655-668.

Kovács, F. 2007. Assessment of Regional Variations in Biomass Production Using Satellite Image Analysis between 1992 and 2004. Transactions in GIS 11. (6): 911-926. Doi:10.1111/j.1467-9671.2007.01080.x

Li, Z., LI, X., WeI, D., XU, X. and WANG, H. 2010. An assessment of correlation on MODIS-NDVI and EVI with natural vegetation coverage in Northern Hebei Province, China. Procedia Environmental Sciences 2. 964-969.

McKee, T.B., Doeskin, N.J. and Kleist, J. 1993. The Relationship of Drought Frequency and Duration to Time Scales. In Proceedings of $8^{\text {th }}$ Conference on Applied Climatology, Anaheim, CA, USA, January 17-22, 1993. Boston, MA, USA, American Meteorological Society, $179-184$.

Mezôsi, G., Blanka, V., Ladányi, Zs., Bata, T., Urdea, P., Frank, A. and Meyer, B. 2016. Expected mid- and long-term changes in drought hazard for the SouthEastern Carpathian Basin. Carpathian Journal of Earth and Environmental Sciences 11. (2): 355-366.

PálfaI, I. 1989. Az Alföld aszályossága (Drought in the Great Hungarian Plain). Alföldi Tanulmányok 13. 7-25. (In Hungarian)

Peel, M.C., Finlayson, B.L. and McMahon, T.A. 2007. Updated world map of the Köppen-Geiger climate classification. Hydrology and Earth System Sciences 11. 1633-1644. Doi:10.5194/hess-11-1633-2007

R Core Team 2013. R: a Language and Environment for Statistical Computing. Vienna, R. Foundation for Statistical Computing.

RAKonCZAI, J. 2011. Effects and Consequences of Global Climate Change in the Carpathian Basin. In Climate Change - Geophysical Foundations and Ecological Effects. Eds.: Blanco, J. and Kheradmand, H. Rijeka, InTech, 297-322.
Renza, D., Martinez, E., Arquero, A. and Sanchez, J. 2010. Drought Estimation Maps by Means of Multidate Landsat Fused Images. In $30^{\text {th }}$ EARSeL Symposium Remote Sensing for Science, Education, and Natural and Cultural Heritage. Proceedings, May 31-June 3, 2010. Ed.: Reuter, R., Paris, UNESCO, 775-782.

Rouse, J.W., Haas, H.R., Schell, A.J. and Deering, W.D. 1973. Monitoring vegetation systems in the Great Plains with ERTS. In Third Earth Resources Technology Satellite-1 Symposium. Volume 1: Technical Presentations, section A. Proceedings, December 10-14, 1973. Eds.: Freden, S.C., Mercanti, E.P. and BECKER, M.A., Washington, D.C., USA, NASA, 309-317.

Roy, D.P., Borak, J.S., Devadiga, S., Wolfe, R.E., Zheng, M. and Descloitres, J. 2002. The MODIS Land Product Quality Assessment Approach. Remote Sensing of Environment 83. 62-76.

Shaw, A.T., Baldwin, M., Barnes, E.A., Caballero, R., Garfinkel, C.I., Hwang, Y., Li, C., O'Gorman, P.A., Rivière, G., Simpson, I.R. and Voigt, A. 2016. Storm track processes and the opposing influences of climate change. Nature Geoscience 9. 656-664. Doi:10.1038/NGEO2783

Solano, R., Didan, K., Jacobson, A. and Huete, A. 2010. MODIS Vegetation Index User's Guide (MOD13 Series). Tucson, The University of Arizona, Vegetation Index and Phenology Laboratory.

Svoboda, M., LeСomte, D., Hayes, M., Heim, R., Gleason, K., Angel, J., Rippey, B., Tinker, R., Palecki, M., Stooksbury, D., Miskus, D. and Stephens, S. 2002. The Drought Monitor. Bulletin of the American Meteorological Society 83. (8): 1181-1190.

Tucker, C.J. 1979. Red and photographic infrared linear combinations for monitoring vegetation. Remote Sensing of Environment 8. (2): 127-150. Doi:10.1016/0034-4257(79)90013-0

TuCKer, C.J. 1980. A spectral method for determining the percentage of green herbage material in clipped samples. Remote Sensing of Environment 9. (2): 175-181. Doi:10.1016/0034-4257(80)90007-3

Vermote, E.F., Котсhenova, S.Y. and Ray, J.P. 2011. MODIS Surface Reflectance User's Guide. Version 1.3. MODIS Land Surface Reflectance Science Computing Facility. http://modis-sr.ltdri.org/guide/ MOD09_UserGuide_v1_3.pdf

VITUKI 2006. A Duna-Tisza közi hátság hidrometeorológiai, felszini és felszín alatti vizeinek mennyiségére vonatkozó mérö-és megfigyelörendszer működtetése és értékelése. Zárójelentés (The operation and evaluation of the hydrometeorological, the surface water and the underground water quantity-related measuring and monitoring system in the Danube-Tisza Interfluve. Final report). Budapest, VITUKI Kht. (In Hungarian) VöLGYesI, I. 2000. A Homokhátság felszinalatti vízháztartása. Vizpótlási és vízvisszatartási lehetőségek (The 
groundwater balance of the Sand Ridge. The possibilities of water supply and water retention). Budapest, VÖLGYESI Mérnökiroda Kft. (In Hungarian)

WANG, L. and QU, J.J. 2007. NMDI: A normalized multi-band drought index for monitoring soil and vegetation moisture with satellite remote sensing. Geophysical Research Letters 34. (20): Doi: 10.1029/2007GL031021

Zhang, D., LI, H. and Zheng, X. 2013. The Moisture Content Prediction Model of Surface Sediment in Intertidal Flat by Hyperspectral Remote Sensing. Geo-information Science 15. (4): 581-589. Doi: 10.3724/ SP.J.1047.2013.00581

Zhang, N., Hong, Y., QIN, Q. and LiU, L. 2013. VSDI: a visible and shortwave infrared drought index for monitoring soil and vegetation moisture based on optical remote sensing. International Journal of Remote Sensing 34. (13): 4585-4609. Doi:10.1080/01 431161.2013.779046
Other sources

CORINE Land Cover Database. http://www.fomi. hu/portal/index.php/projektjeink/foldfelszinmonitorozas-corine

DM (United States Drought Monitor). http://droughtmonitor.unl.edu/

EDO (European Drought Observatory): http://edo.jrc. ec.europa.eu/edov2/php/index.php?id=1000

EEA (European Environmental Agency). https:// www.eea.europa.eu/publications/COR0-landcover GLOVIS (USGS Global Visualization Viewer) https:// glovis.usgs.gov/

HCSO (KSH in Hungarian). http://www.ksh.hu/ HMS (OMSZ in Hungarian). http://met.hu/en/idojaras/ ICID http://www.icid.org/wg_drought.html WMO (World Meteorological Organization). http:// www.wmo.int/pages/prog/wcp/ccl/faqs.php 